\title{
PENGARUH MODEL PEMBELAJARAN KOOPERATIF TIPE NUMBERED HEAD TOGETHER (NHT) TERHADAP PEMAHAMAN KONSEP MATEMATIS SISWA KELAS VIII SMP NEGERI 53 BATAM
}

\author{
Eka Rahmawati, Yesi Gusmania* \\ Program Studi Pendidikan Matematika, Fakultas Keguruan dan Ilmu Pendidikan \\ Universitas Riau Kepulauan, Batam, Kepulauan Riau, Indonesia \\ e-mail : yesigusmania18@gmail.com
}

\begin{abstract}
Abstrak. Tujuan penelitian ini adalah untuk mengkaji pengaruh pemahaman konsep matematis siswa dengan menerapkan model pembelajaran kooperatif tipe Numbered Heads Together (NHT). Penelitian ini menggunakan metode kuantitatif dengan jenis penelitian eksperimen semu dan desain penelitian menggunakan pretest-posstest control group design. Populasi dalam penelitian ini seluruh siswa SMP Negeri 53 Batam terdiri dari 5 kelas dengan jumlah siswa 193 orang. Teknik pengambilan sampel menggunakan teknik cluster random sampling. Dari lima kelas yang terundi kelas VIII.A sebagai kelas eksperimen dengan model pembelajaran NHT dan VIII. . $_{\text {s }}$ sebagai kelas kontrol dengan pembelajaran konvensional. Instrumen penelitian yaitu tes uraian sebanyak 5 soal berupa pretest dan posttest. Teknik analisis data terdiri dari uji normalitas menggunakan chi kuadrat dan homogenitas menggunakan Uji F dilanjutkan uji hipotesis menggunakan uji-t dua sampel berpasangan, dan uji dua sampel dengan rumus t-test polled variansi. Berdasarkan analisis hipotesis data menggunakan rumus uji-t dua sampel berpasangan (paired sample t-test) diperoleh $t_{\text {hitung }}>t_{\text {tabel }}(7,26>1,66)$ sedangkan kelas kontrol $\mathrm{t}_{\text {hitung }}>\mathrm{t}_{\text {tabel }}(4,68>1,66)$. Selanjutnya menggunakan rumus $t$-test polled variansi dengan hasil bahwa $t_{\text {hitung }}>t_{\text {tabel }}(1,84>1,66)$. Maka dapat disimpulkan bahwa terdapat pengaruh penggunaan model pembelajaran Numbered Heads Together (NHT) dan konvensional terhadap pemahaman konsep matematis siswa kelas VIII SMP Negeri 53 Batam. Dan terdapat perbedaan antara model pembelajaran kooperatif tipe Numbered Heads Together (NHT) dengan model pembelajaran konvensional terhadap pemahaman konsep matematis siswa kelas VIII SMP N 53 Batam Tahun Pelajaran 2016/2017 pada pokok bahasan operasi aljabar.
\end{abstract}

Kata kunci: Numbered Heads Together (NHT), Pembelajaran konvensional, pemahaman konsep matematis.

Abstract. The purpose of this study was to examine the influence of students' understanding of mathematical concepts by applying cooperative learning model Numbered Heads Together (NHT). This study uses quantitative methods to the type of experimental research and research design using pretest-posstest control group design. Population in this research all student of SMP country 53 Batam consisted by five class summed uply is student 193 people. Determination of the sample using random cluster sampling technique. VIII.A class as an experimental class NHT and VIII.B as conventional control class. The research instruments that test the form pretest and posttest. Data analysis technique consists of the prerequisite test for normality using chi square and continued homogeneity using $\mathrm{F}$ test the hypothesis test using t-test two paired samples, and test the two parties. Based on data analysis using the formula samples t-test two pairs (paired sample t-test) then obtained in the experimental class $t_{\text {hitung }}>t_{\text {tabel }}(7.26>1.66)$, while the control class $t_{\text {hitung }}>t_{\text {tabel }}(4.68>1.66)$, For the third hypothesis using the formula polled variance t-test (test two parties) with the result that tcount $>$ ttabel $(1.84>1.66)$. It can be concluded that there are significant use of the learning model Numbered Heads Together (NHT) and conventional to the understanding of mathematical concepts eighth grade 
students of SMP Negeri 53 Batam. And there is a difference between cooperative learning model Numbered Heads Together (NHT) with conventional learning models to the understanding of mathematical concepts eighth grade students of SMP Negeri 53 Batam in the school year 2016/2017 on the subject of algebra operations.

Keywords: Learning Model Numbered Heads Together (NHT), conventional learning models, understanding of mathematical concepts.

\section{Pendahuluan}

Matematika memuat suatu kumpulan konsep dan operasi-operasi, tetapi didalam pengajaran matematika pemahaman siswa mengenai hal-hal yang lebih objektif dibanding mengembangkan kekuatannya dalam perhitungan-perhitungannya (Heris \& Utari, 2014: 7). Dalam pembelajaran matematika aspek kognitif mencakup perilaku-perilaku yang menekankan aspek intelektual seperti kemampuan matematis (mathematical abilities), yaitu pengetahuan dan keterampilan dasar yang diperlukan untuk dapat melakukan manipulasi matematika dan kemampuan berpikir dalam matematika. Kemampuan matematis diantaranya adalah kemampuan pemahaman matematis (understanding) yaitu kemampuan menyerap dan memahami ide-ide matematika (Karunia \& Mokhammad, 2015: 81). Pemahaman dalam matematika juga merupakan tujuan utama dari setiap materi yang disampaikan oleh guru untuk mencapai konsep yang diinginkan.

Berdasarkan observasi di SMP Negeri 53 Batam pada tanggal 01 Maret 2016 bahwa pembelajaran yang dilakukan di dalam kelas masih didominasi guru dengan metode ceramah. Sebagian besar siswa cenderung kurang memperhatikan dan kurang aktif saat pembelajaran berlangsung. Pembelajaran dimulai dari guru memberikan materi, menjelaskan materi pelajaran, memberikan contoh soal, tanya jawab, latihan soal, dan pemberian tugas. Saat guru bertanya kepada siswa apakah sudah mengerti atau belum, kebanyakan siswa diam, guru menganggap kalau siswanya sudah paham dan mengerti padahal siswa belum tentu mengerti, dan guru melanjutkan kepokok bahasan selanjutnya. Hal ini berdampak pada rendahnya kemampuan pemahaman konsep matematis siswa. Selain itu berdasarkan rata-rata nilai UAS semester ganjil hasilnya masih kurang dari KKM yaitu 71. Berikut hasil UAS semester ganjil Kelas VIII SMPN 35 Batam tahun pelajaran 2015/2016.

Tabel 1. Rata-rata nilai UAS Semester Ganjil Kelas VIII SMPN 53 Batam

\begin{tabular}{cccccc}
\hline No & Kelas & Rata-rata & \% Tuntas & \% Tidak tuntas & KKM \\
\hline 1 & VIII.A & 60,39 & 41 & 59 & \\
2 & VIII.B & 50,97 & 42 & 58 & \\
3 & VIII.C & 51,50 & 41,5 & 58,5 & 71 \\
4 & VIII.D & 48,90 & 41 & 59 & \\
5 & VIII.E & 50,01 & 40,7 & 59,3 & \\
\hline
\end{tabular}

Sumber: Guru Mata Pelajaran Matematika Kelas VIII SMPN 53 Batam

Sebagai seorang guru, tentunya selalu berusaha dan berharap agar siswanya selalu mengikuti pembelajaran dengan baik, sehingga kompetensi yang diharapkan dapat tercapai. Keadaan tersebut dapat juga dikatakan bahwa seorang guru berusaha dan mengharapkan pemahaman konsep belajar siswa dapat meningkat. Tetapi kenyataannya masih cukup jauh 
dari apa yang diharapkan, kebanyakan siswa kurang antusias dalam mengikuti proses pembelajaran, kurangnya pemahaman konsep disebabkan matematika dianggap pelajaran yang rumit, terlalu banyak menggunakan angka dan rumus.

Pemahaman konsep akan lebih baik, jika guru dapat melibatkan siswa secara aktif dalam proses pembelajarannya. Menurut purwanto (dalam Sonni, 2014) mengungkapkan bahwa pemahaman konsep adalah tingkat kemampuan yang mengharapkan siswa mampu memahami konsep, situasi, dan fakta yang diketahui, serta dapat menjelaskan dengan katakata sendiri sesuai dengan pengetahuan yang dimilikinya, tanpa mengubah artinya. Hal ini juga sejalan dengan pendapat Sudijono (dalam Khumaidi, 2011), pemahaman adalah kemampuan seseorang untuk mengerti atau memahami sesuatu itu diketahui dan diingat. Dengan kata lain memahami adalah mengetahui tentang sesuatu dan dapat melihatnya dari berbagai segi. Dari kedua pendapat dapat disimpulkan bahwa pemahaman atau understanding mempunyai beberapa tingkat kedalaman arti yang berbeda. Pemahaman adalah proses, cara, perbuatan memahami, atau memahamkan. Pemahaman berhubungan dengan kemampuan untuk menjelaskan pengetahuan atau informasi yang telah diketahui dengan kata-kata sendiri, sehingga siswa diharapkan dapat menterjemahkan dan menyebutkan kembali yang telah di dengar dengan kata-kata sendiri.

Indikator kemampuan pemahaman konsep matematis yaitu: (Karunia \& Mokhammad, 2015: 81)

1) Menyatakan ulang konsep yang telah dipelajari

2) Mengklasifikaikan objek-objek berdasarkan konsep matematika

3) Menerapkan konsep secara logaritma

4) Memberikan contoh atau kontra contoh dari konsep yang dipelajari

5) Menyajikan konsep dalam berbagai representasi

6) Mengaitkan berbagai konsep matematika secara internal atau eksternal

Model pembelajaran pada pelajaran tentunya dapat mempengaruhi proses belajar mengajar di kelas dan pemahaman konsep belajar siswa. Salah satu model pembelajaran yang melibatkan siswa secara aktif dalam proses pembelajaran adalah model pembelajaran kooperatif tipe NHT. Menurut Trianto (2009: 82) menyatakan NHT (Numbered Heads Together) atau penomoran berpikir bersama merupakan jenis pembelajaran kooperatif yang dirancang untuk mempengaruhi pola interaksi siswa dan sebagai alternatif terhadap struktur kelas tradisional.

Penerapan model pembelajaran NHT ini, siswa akan dibagi dalam kelompok yang beranggotakan 3-5 orang. Pengelompokan siswa ini berdasarkan nilai hasil pretest, sehingga dalam tiap kelompok memiliki anggota yang bervariasi tingkat kemampuan, jenis kelamin, dan latar belakang etniknya. Secara umum teman satu kelompok mengerjakan suatu permasalahan matematika secara diskusi bersama, kemudian setelah selesai berdiskusi dan mengerjakan soal-soal yang diberikan, guru menyebutkan salah satu nomor kemudian siswa yang memiliki nomor yang disebutkan oleh guru mempresentasikan hasil diskusi kelompoknya di depan kelas (Sonni, 2014). Didalam pembelajaran model NHT yang mengarahkan agar siswa dapat berpikir bersama dalam berdiskusi, mencari dan menemukan 
solusi permasalahan serta menyelidiki materi/soal yang dibahas secara bersama sehingga hasil yang diperoleh siswa akan mengetahui semua jawaban anggota kelompoknya.

Tujuan penelitian adalah: (1) Untuk mengetahui pengaruh penggunaan model pembelajaran kooperatif tipe Numbered Heads Together (NHT) terhadap pemahaman konsep matematis siswa Kelas VIII SMP Negeri 53 Batam, (2) Untuk mengetahui pengaruh penggunaan model pembelajaran konvensional terhadap pemahaman konsep matematis siswa Kelas VIII SMP Negeri 53 Batam, (3) Untuk mengetahui perbedaan antara model pembelajaran kooperatif tipe Numbered Heads Together (NHT) dengan model pembelajaran konvensional ditinjau dari pemahaman konsep matematis siswa Kelas VIII SMP Negeri 53.

\section{Metodologi Penelitian}

Jenis penelitian ini adalah penelitian quasi eksperimen. Desain dalam penelitian ini menggunakan "Pretest-Posttest Control Group Design".

Tabel 2. Rancangan Desain Penelitian

\begin{tabular}{cccc}
\hline Kelompok & Tes Awal & Perlakuan & Tes Akhir \\
\hline Eksperimen $(\mathrm{R})$ & $\mathrm{O}_{1}$ & $\mathrm{X}$ & $\mathrm{O}_{2}$ \\
Kontrol (R) & $\mathrm{O}_{3}$ & - & $\mathrm{O}_{4}$ \\
\hline
\end{tabular}

Sumber: Sugiyono, (2010: 112)

Keterangan:

$\mathrm{R}=$ Random

$\mathrm{O}_{1}=$ Nilai pretest $($ sebelum diberi perlakuan) pada kelas Eksperimen

$\mathrm{O}_{2}=$ Nilai posttest (setelah diberi perlakuan) pada kelas Eksperimen

$\mathrm{O}_{3}=$ Nilai pretest pada kelas kontrol

$\mathrm{O}_{4}=$ Nilai posttest pada kelas kontrol

$\mathrm{X}=$ Perlakuan dengan menggunakan model pembelajaran Numbered Heads Together (NHT) dan kelas kontrol dengan pembelajaran konvensional tanpa diberi perlakuan

Menurut Sugiyono (2012:117) populasi adalah wilayah generalisasi yang terdiri atas : objek / subyek yang mempunyai kualitas dan karakteristik tertentu yang ditetapkan oleh peneliti untuk mempelajari dan kemudian ditarik kesimpulannya. Populasi dalam penelitian ini adalah seluruh siswa kelas VIII SMP Negeri 53 Batam semester genap tahun pelajaran 2016/2017 berjumlah 193 orang. Teknik pengambilan sampel dilakukan dengan cluster random sampling. Dari lima kelas VIII yang ada di SMP Negeri 53 Batam dipilih secara acak dua kelas sebagai sampel dengan cara diundi. Hasil undian didapatkan kelas VIII. A terpilih sebagai kelas eksperimen dengan pembelajaran kooperatif tipe Numbered Heads Together (NHT) dan kelas VIII.B terpilih sebagai kelompok kelas kontrol dengan pembelajaran konvensional.

Variabel bebas dalam penelitian ini adalah model pembelajaran kooperatif (NHT) dan kelas kontrol dengan menggunakan pembelajaran konvensional. Sedangkan variabel terikat adalah kemampuan pemahaman konsep matematis siswa. Instrumen dalam penelitian ini adalah tes berupa soal uraian sebanyak 5 soal dengan pokok bahasan operasi aljabar. Teknik 
analisis instrumen yang digunakan dalam penelitian ini yaitu validitas isi dengan metode CVR, reliabilitas, tingkat kesukaran soal, dan daya beda soal. Teknik analisis data terdiri dari uji normalitas menggunakan chi kuadrat dan homogenitas menggunakan Uji $F$ dilanjutkan uji hipotesis menggunakan uji-t dua sampel berpasangan (paired sample t-test), dan t-test polled varians.

Hipotesis dalam penelitian adalah:

$\mathrm{H}_{01}$ : Tidak terdapat pengaruh penggunaan model pembelajaran kooperatif tipe Numbered Heads Together (NHT) terhadap pemahaman konsep matematis siswa Kelas VIII SMP Negeri 53 Batam Tahun Pelajaran 2016/2017.

$\mathrm{H}_{\mathrm{a} 1}$ : Terdapat pengaruh penggunaan model pembelajaran kooperatif tipe Numbered Heads Together (NHT) terhadap pemahaman konsep matematis siswa Kelas VIII SMP Negeri 53 Batam Tahun Pelajaran 2016/2017.

$\mathrm{H}_{02}$ : Tidak terdapat pengaruh penggunaan model pembelajaran konvensional terhadap pemahaman konsep matematis siswa Kelas VIII SMP Negeri 53 Batam Tahun Pelajaran 2016/2017.

$\mathrm{H}_{\mathrm{a} 2}$ : Terdapat pengaruh penggunaan model pembelajaran konvensional terhadap pemahaman konsep matematis siswa Kelas VIII SMP Negeri 53 Batam Tahun Pelajaran 2016/2017.

$\mathrm{H}_{03}$ : Tidak terdapat perbedaan antara model pembelajaran kooperatif tipe Numbered Heads Together (NHT) dengan model pembelajaran konvensional ditinjau dari pemahaman konsep matematis siswa Kelas VIII SMP Negeri 53 Batam Tahun Pelajaran 2016/2017.

$\mathrm{H}_{\mathrm{a} 3}$ : Terdapat perbedaan antara model pembelajaran kooperatif tipe Numbered Heads Together (NHT) dengan model pembelajaran konvensional ditinjau dari pemahaman konsep matematis siswa Kelas VIII SMP Negeri 53 Batam Tahun Pelajaran 2016/2017.

\section{Hasil Penelitian dan Pembahasan}

Uji Normalitas dan homogenitas sebelum perlakuan (Pretest)

Tabel 3. Perhitungan Normalitas (Pretest)

\begin{tabular}{ccc}
\hline Keterangan & NHT & Konvensional \\
\hline$\chi^{2}{ }_{\text {hitung }}$ & 2,89 & 3,27 \\
$\chi^{2}{ }_{\text {tabel }}$ & 11,07 & 11,07 \\
Kriteria & & $\chi_{\text {hitung }}^{2}<\chi_{\text {tabel }}^{2}$ \\
\end{tabular}

Karena pada kelas NHT dan konvensional $\chi^{2}$ hitung $<\chi_{\text {tabel }}^{2}$ maka dapat disimpulkan kedua sampel tersebut berasal dari populasi yang berdistribusi normal. 
Tabel 4. Perhitungan Homogenitas (Pretest)

\begin{tabular}{|c|c|c|}
\hline Keterangan & Eksperimen & Kontrol \\
\hline Jumlah sampel & 38 & 39 \\
\hline Variansi $\left(S^{2}\right)$ & 89,67 & 81,43 \\
\hline $\mathrm{F}_{\text {hitung }}$ & \multicolumn{2}{|c|}{1,1} \\
\hline $\mathrm{F}_{\text {tabel }}$ & \multicolumn{2}{|c|}{1,76} \\
\hline Kesimpulan & \multicolumn{2}{|c|}{ Data Homogen } \\
\hline
\end{tabular}

Karena $F_{\text {hitung }}<\mathrm{F}_{\text {tabel }}$, maka dapat disimpulkan bahwa variansi dari kelompok sampel homogen (sama).

Uji Normalitas setelah perlakuan

Uji Normalitas menggunakan uji chi kuadrat dimana taraf signifikansi yang digunakan adalah 5\% dengan dk (derajat kebebasan) 6-1=5.

Tabel 5. Uji Normalitas Kelas Eksperimen

\begin{tabular}{cccccc}
\hline Interval & $f_{0}$ & $f_{h}$ & $f_{0}-f_{h}$ & $\left(f_{0}-f_{h}\right)^{2}$ & $\frac{\left(f_{0}-f_{h}\right)^{2}}{f_{h}}$ \\
\hline $58-64$ & 2 & 1 & 1 & 1 & 1 \\
$65-71$ & 4 & 5 & -1 & 1 & 0,8 \\
$72-78$ & 10 & 13 & -3 & 9 & 0,69 \\
$79-85$ & 12 & 13 & -1 & 1 & 0,08 \\
$86-92$ & 7 & 5 & 2 & 4 & 0,8 \\
$93-99$ & 3 & 1 & 2 & 4 & 4 \\
Jumlah & 38 & 38 & 0 & 20 & 7,37 \\
\hline
\end{tabular}

karena $\chi_{\text {hitung }}^{2}<\chi_{\text {tabel }}^{2}, 7,37<11,07$ maka data kelas eksperimen berdistribusi normal.

Tabel 6. Uji Normalitas Kelas Kontrol

\begin{tabular}{cccccc}
\hline Interval & $f_{0}$ & $f_{h}$ & $f_{0}-f_{h}$ & $\left(f_{0}-f_{h}\right)^{2}$ & $\frac{\left(f_{0}-f_{h}\right)^{2}}{f_{h}}$ \\
\hline $58-64$ & 3 & 1 & 2 & 4 & 4 \\
$65-71$ & 6 & 5,2 & 1,2 & 1,44 & 0,28 \\
$72-78$ & 11 & 13,3 & $-2,3$ & 5,29 & 0,4 \\
$79-85$ & 12 & 13,3 & $-1,3$ & 1,69 & 0,13 \\
$86-92$ & 5 & 5,2 & $-0,2$ & 0,04 & 0,01 \\
$93-99$ & 2 & 1 & 1 & 1 & 1 \\
Jumlah & 39 & 39 & 0,4 & & 5,82 \\
\hline Karena $\chi_{\text {hitung }}^{2}<\chi_{\text {tabel }}^{2}, 5,82<11,07$ maka data kelas kontrol berdistribusi normal.
\end{tabular}

Uji Homogenitas setelah perlakuan: 


$$
\mathrm{F}_{\text {hitung }}=\frac{\text { varian terbesar }}{\text { varian terkecil }}=\frac{88,64}{72,09}=1,23
$$

$F_{\text {hitung }}$ dibandingkan dengan harga $F_{\text {tabel }}$ dengan dk pembilang $=\left(n_{2}-1\right)$ dan dk penyebut $=\left(n_{1}-1\right)$ maka didapat $F_{\text {tabel }}=1,76$. Sehingga $F_{\text {hitung }}<F_{\text {tabel }}(1,23<1,76)$, maka data kedua kelas dinyatakan homogen.

Hasil Uji t dua sampel berpasangan (paired sample t-test)

Tabel 7. Pemahaman Konsep Matematis Kelas Eksperimen

\begin{tabular}{ccc}
\hline \multicolumn{3}{c}{ Kelas Ekperimen (NHT) } \\
\hline Keterangan & Pretest & Posttest \\
\hline Jumlah sampel & 38 & 38 \\
Rata-rata & 70,82 & 80,84 \\
Variansi $\left(\mathrm{S}^{2}\right)$ & 89,67 & 72,09 \\
St.dev & 9,47 & 8,49 \\
\hline$t_{\text {hitung }}$ & & \\
\hline$t_{\text {tabel }}$ & & 1,26 \\
\hline
\end{tabular}

Berdasarkan tabel di atas diperoleh $t_{\text {hitung }}>t_{\text {tabel }}(7,26>1,66)$ maka diperoleh $\mathrm{H}_{\mathrm{a}}$ diterima artinya terdapat pengaruh penggunaan model pembelajaran kooperatif tipe Numbered Heads Together (NHT) terhadap pemahaman konsep matematis siswa Kelas VIII SMP Negeri 53 Batam Tahun Pelajaran 2016/2017 pokok bahasan operasi aljabar.

Tabel 8. Pemahaman Konsep Matematis Kelas Kontrol

\begin{tabular}{ccc}
\hline \multicolumn{3}{c}{ Kelas Kontrol (Konvensional) } \\
\hline Keterangan & Pretest & Posttest \\
Jumlah sampel & 39 & 39 \\
Rata-rata & 68,57 & 77,13 \\
Variansi $\left(\mathrm{S}^{2}\right)$ & 81,43 & 88,64 \\
St.dev & 9,02 & 9,14 \\
\hline$t_{\text {hitung }}$ & & \\
\hline$t_{\text {tabel }}$ & 4,68 \\
\hline
\end{tabular}

Berdasarkan tabel di atas diperoleh $t_{\text {hitung }}>t_{\text {tabel }}(4,68>1,66)$, maka $\mathrm{H}_{a}$ diterima artinya terdapat pengaruh penggunaan model pembelajaran konvensional terhadap pemahaman konsep matematis siswa kelas VIII SMP Negeri 53 Batam Tahun Pelajaran 2016/2017 pokok bahasan operasi aljabar. 
Tabel 9. Hasil Uji t-test polled variansi (kelas eksperimen dan kontrol)

\begin{tabular}{ccc}
\hline Keterangan & Eksperimen & Kontrol \\
\hline Mean & 80,84 & 76,92 \\
St.dev $(\mathrm{s})$ & 8,49 & 9,45 \\
$\mathrm{~N}$ & 38 & 39 \\
Varians $\left(S^{2}\right)$ & 81,43 & 79,63 \\
\hline$t_{\text {hitung }}$ & 1,84 \\
\hline$t_{\text {tabel }}$ & 1,66 \\
\hline
\end{tabular}

Berdasarkan tabel di atas diperoleh $t_{\text {hitung }}>t_{\text {tabel }}(1,84>1,66)$, maka $\mathrm{H}_{\mathrm{a}}$ diterima artinya terdapat perbedaan antara model pembelajaran kooperatif tipe Numbered Heads Together (NHT) dengan model pembelajaran konvensional ditinjau dari pemahaman konsep matematis siswa kelas VIII SMP Negeri 53 Batam Tahun Pelajaran 2016/2017 pada pokok bahasan operasi aljabar.

Pelaksanaan dengan model NHT dan pembelajaran konvensional pada saat proses pembelajaran:

(1) Kelas eksperimen dengan model NHT

Berdasarkan pengamatan dikelas dari beberapa pertemuan, siswa-siswa memiliki antusias yang besar saat proses pembelajaran dan saat berdiskusi, siswa terlihat lebih semangat dalam memahami materi. Dan juga terlihat pemahaman konsep matematis pada saat posttest diberikan. Pemahaman konsep matematis siswa lebih baik dari kelas kontrol. Siswa dapat menyelesaikan soal pemahaman konsep matematis pada indikator pertama dan kedua yaitu menyatakan ulang suatu konsep dan memberikan contoh dan non contoh dari konsep. Hal ini juga sejalan dengan pendapat Sonni (2014) bahwa ada faktor pendukung dalam pemahaman konsep matematis siswa pada model NHT antara lain: (1) Siswa menjadi lebih semangat karena pembelajaran berbentuk diskusi kelompok. Pada saat proses belajar siswa termotivasi untuk memahami materi pelajaran yang dipersentasikan oleh guru yang nantinya akan diberi soal-soal untuk berdiskusi, (2) Siswa yang menjadi perwakilan kelompok/nomor kepala yang ditunjuk guru untuk memberikan jawaban dan mempresentasikannya di depan kelas dan setiap anggota kelompok wajib mengetahui tentang jawaban yang akan dipresentasikan, kemudian perwakilan dari kelompok lain dengan nomor kepala yang sama akan memberi jawaban/mempresentasikan jawaban juga. Jika ada yang melenceng guru akan mengarahkan dan memberikan jawaban yang benar, (3) Pemahaman konsep matematis siswa menjadi meningkat dalam waktu yang sedikit karena siswa berusaha untuk menjawab setiap soal-soal yang diberikan, (4) Siswa dapat bersosialisasi dengan orang lain baik itu dalam kelompoknya sendiri maupun dengan kelompok yang lain.

(2) Kelas kontrol dengan pembelajaran konvensional

Berdasarkan beberapa pertemuan dikelas bahwa model pembelajaran konvensional di kelas ini membawa hasil pemahaman konsep matematis yang baik.

Hal ini juga terlihat dari hasil pemahaman konsep matematis pada saat posttest diberikan. dapat di lihat pada tabel 10 di bawah ini. 
Tabel 10. Nilai per-indikator Pemahaman konsep matematis siswa kelas NHT dan konvensional

\begin{tabular}{|c|c|c|c|c|}
\hline No & Indikator & NHT & konvensional & Selisih \\
\hline 1 & Menyatakan ulang sebuah konsep & 8,04 & 7,61 & 0,43 \\
\hline 2 & $\begin{array}{l}\text { Memberikan contoh dan non } \\
\text { contoh dari konsep }\end{array}$ & 7,82 & 7,39 & 0,43 \\
\hline 3 & $\begin{array}{l}\text { Menyajikan konsep dalam } \\
\text { berbagai bentuk representasi } \\
\text { matematis }\end{array}$ & 15,22 & 14,78 & 0,44 \\
\hline 4 & $\begin{array}{l}\text { Mengaplikasikan konsep atau } \\
\text { algoritma pemecahan masalah }\end{array}$ & 49,76 & 47,35 & 2,41 \\
\hline & Jumlah & 80,84 & 77,13 & 3,71 \\
\hline
\end{tabular}

Berdasarkan Tabel 10 diperoleh nilai rata-rata secara keseluruhan untuk kelompok kelas eksperimen NHT lebih tinggi dibandingkan dengan kelas konvensional dengan selisih 3,71 artinya skor jawaban kelas NHT lebih tinggi dari rata-rata kelas konvensional dan pemahaman konsep matematis siswa NHT lebih baik daripada konvensional. Setiap indikator pemahaman konsep matematis siswa kelas NHT lebih ditinggi dibandingkan konvensional. Hal ini juga terdapat perbedaan antara model pembelajaran kooperatif tipe Numbered Heads Together (NHT) dengan model pembelajaran konvensional ditinjau dari pemahaman konsep matematis siswa kelas VIII SMP Negeri 53 Batam Tahun Pelajaran 2016/2017 pada pokok bahasan operasi aljabar.

\section{Kesimpulan}

1. Terdapat pengaruh penggunaan model pembelajaran kooperatif tipe Numbered Heads Together (NHT) terhadap pemahaman konsep matematis siswa Kelas VIII SMP Negeri 53 Batam Tahun Pelajaran 2016/2017 pokok bahasan operasi aljabar.

2. Terdapat pengaruh penggunaan model pembelajaran konvensional terhadap pemahaman konsep matematis siswa Kelas VIII SMP Negeri 53 Batam Tahun Pelajaran 2016/2017 pokok bahasan operasi aljabar.

3. Terdapat perbedaan antara penggunaan model pembelajaran kooperatif tipe Numbered Heads Together (NHT) dengan model pembelajaran konvensional ditinjau dari pemahaman konsep matematis siswa Kelas VIII SMP Negeri 53 Batam Tahun Pelajaran $2016 / 2017$.

\section{Daftar Pustaka}

Agus Suprijono. (2014). Cooperative Learning. Yogyakarta: Pustaka Pelajar

Heris \& Utari. (2014). Penilaian Pembelajaran Matematika. Bandung: Refika Aditama.

Karunia \& Mokhammad. (2015). Penelitian Pendidikan Matematika. Bandung: Refika Aditama. 
Khumaidi, M. (2011). Upaya Peningkatan Pemahaman Konsep Bangun Ruang ssi Datar dengan Menggunakan Media Manipulatif. Jakarta: Universitas Islam Negeri Syarif Hidayatullah Jakarta. Skripsi tidak diterbitkan.

Sonni Permana Sakti. (2014). Efektivitas Pembelajaran Dengan Pendekatan Pemecahan Masalah (Problem Solving) Dalam Setting Pembelajaran Kooperatif Tipe Numbered Head Together (NHT) Ditinjau Dari Peningkatan Pemahaman Konsep Dan Komunikasi Matematis Siswa Smp Negeri 1 Prambanan Kelas VIII. Yogyakarta: Universitas Negeri Yogyakarta. Skripsi tidak diterbitkan.

Sugiyono. (2012). Statistika untuk Penelitian. Bandung: Alfabeta

Sugiyono. (2010). Metode Penelitian Pendidikan. Bandung: Alfabeta.

Trianto. (2009). Mendesain Model Pembelajaran Inovatif-Progresif. Surabaya: Kencana. 